Journal of Information System, Applied, Management, Accounting and Research. http://journal.stmikjayakarta.ac.id/index.php/jisamar, jisamar@stmikjayakarta.ac.id , jisamar2017@gmail.com

e-ISSN: 2598-8719 (Online), p-ISSN: 2598-8700 ( Printed), Vol. 5 No.2 Mei 2021

\title{
PENGARUH PENGUNGKAPAN CORPORATE SOCIAL RESPONSIBILITY TERHADAP PROFITABILITAS PERUSAHAAN (Studi Empiris pada Perusahaan Sektor Industri Rokok yang Terdaftar di Bursa Efek Indonesia Tahun 2016-2019)
}

\author{
Anikmah Musfirati ${ }^{1}$, Lorensius Ginting ${ }^{2}$, Muhammad \\ Lukman Nur Hakim ${ }^{3}$ \\ Politeknik Keuangan Negara STAN \\ 1401170063 anikmah@pknstan.ac.id, \\ 1401170043 lorensius@pknstan.ac.id , \\ 1401170026 lukman@pknstan.ac.id
}

\begin{abstract}
Abstrak: Corporate Social Responsibility (CSR) atau Tanggung Jawab Sosial dan Lingkungan merupakan kewajiban perusahaan (perseroan) yang diperhitungkan sebagai biaya perseroan yang pelaksanaannya dilakukan dengan memperhatikan kepatutan dan kewajaran sesuai dengan UU No 40 tahun 2007. Di sisi lain, CSR juga merupakan sarana untuk meningkatkan laba perusahaan dengan membangun reputasi sebagai warga social. Penelitian ini bertujuan untuk mengetahui pengaruh tingkat pengungkapan CSR terhadap profitabilitas perusahaan di sector industri rokok yang terdaftar di BEI tahun 2016 - 2019. Tingkat pengungkapan CSR diukur menggunakan CSR Disclosure Index. Sedangkan profitabilitas perusahaan digambarkan dengan Net Profit Margin (NPM) dan Return on Asset (ROA). Dengan menggunakan teknik analisis data regresi linear serta dilakukan uji secara simultan (Uji F) maupun parsial (Uji t) dengan tingkat kepercayaan 95\% ( $\alpha=5 \%)$, dihasilkan simpulan bahwa pengungkapan CSR berpengaruh secara signifikan terhadap ROA namun pengungkapan CSR tidak memiliki pengaruh yang signifikan terhadap NPM.
\end{abstract}

Kata kunci: Pengungkapan CSR, NPM, dan ROA

\section{LATAR BELAKANG}

Dalam menjalankan bisnis, perusahaan dihadapkan pada dua kondisi yang saling bertentangan. Di satu sisi, perusahaan berupaya untuk meningkatkan laba dan salah satu cara

DOI: $10.52362 /$ jisamar.v5i2.379

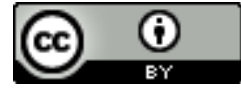

Ciptaan disebarluaskan di bawah Lisensi Creative Commons Atribusi 4.0 Internasional 
Journal of Information System, Applied, Management, Accounting and Research.

http://journal.stmikjayakarta.ac.id/index.php/jisamar,

jisamar@stmikjayakarta.ac.id , jisamar2017@gmail.com

e-ISSN: 2598-8719 (Online), p-ISSN: 2598-8700 ( Printed), Vol. 5 No.2 Mei 2021

untuk meningkatkan laba tersebut adalah melalui penekanan biaya, khususnya biaya-biaya yang tidak berkaitan langsung dengan produksi dan pemasaran produk. Di sisi lain, perusahaan juga harus bertanggung jawab atas seluruh dampak sosial yang timbul atas bisnis yang mereka lakukan. Tanggung jawab sosial perusahaan atas dampak yang mereka timbulkan disebut dengan Corporate Social Responsibility (CSR).

Perusahaan rokok merupakan salah satu sektor perusahaan yang memberikan dampak sosial negatif kepada masyarakat. Ada dampak positif seperti ketersediaan lapangan pekerjaan dan efek ekonomi kepada masyarakat melalui pembayaran pajak. Perusahaan dalam industri rokok ini merupakan salah satu sektor industri yang memberikan kontribusi signifikan terhadap perekonomian nasional. Pada tahun 2018 misalnya, data Kementerian Keuangan menunjukkan bahwa setoran ke kas negara melalui cukai rokok mencapai Rp153 triliun. Dibalik dampak positif yang ditimbulkan, ada dampak negative mulai dari keselamatan pengguna produk, efek sosial kehadiran produk dan juga dampak lingkungan yang ditimbulkan oleh kegiatan industri, seperti pencemaran lingkungan.

Perusahaan bertanggung jawab atas dampak positif dan negatif tersebut.Mereka bertanggungjawab untuk memaksimalkan dampak positif dan di sisi lain harus melakukan berbagai upaya untuk meminimalkan dampak negatif dari bisnis mereka.

Corporate social responsibility (CSR) ini tentu saja meningkatkan beban keuangan perusahaan. Perusahaan harus menyediakan dana yang tidak sedikit untuk melaksanakan tanggung jawab sosial mereka. Di sisi lain, perusahaan akan mendapatkan citra yang positif di masyarakat ketika perusahaan melaksanakan CSR mereka dengan baik. Citra positif ini dapat memberikan dampak positif pada keuangan perusahaan. Masyarakat akan cenderung untuk memilih produk dari perusahaan yang memiliki citra positif di lingkungan mereka. Survey yang dilakukan Booth-Harris Trust Monitor (2001) dalam Sutopoyudo (2009), menunjukkan bahwa mayoritas konsumen akan meninggalkan suatu produk yang mempunyai citra buruk atau diberitakan negative. Dengan demikian, pelaksanaan CSR akan meningkatkan penjualan perusahaan dan pada akhirnya akan meningkatkan profitabilitas perusahaan. Oleh karena itu, CSR juga berperan penting dalam meningkatkan nilai perusahaan.

Pelaksanaan CSR memberikan banyak manfaat bagi perusahaan. Produk perusahaan akan semakin disukai oleh konsumen dan perusahaan juga akan semakin diminati investor. CSR juga dapat dijadikan sebagai alat marketing baru bagi perusahaan jika CSR tersebut dilaksanakan secara berkelanjutan oleh perusahaan.

Dengan demikian,penerapan CSR perusahaan memiliki dampak yang negative dan positif terhadap keuangan perusahaan. Penerapan CSR akan meningkatkan beban perusahaan melalui penyediaan dana untuk implementasi CSR dan di sisi lain juga akan meningkatkan keuntungan perusahaan akibat dari citra positif perusahaan yang ada di masyarakat.

DOI: $10.52362 /$ jisamar.v5i2.379

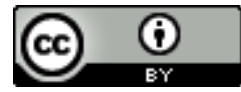

Ciptaan disebarluaskan di bawah Lisensi Creative Commons Atribusi 4.0 Internasional 
Pembahasan diatas menunjukkan bahwa masyarakat memiliki perhatian yang tinggi terhadap isu-isu kepedulian sosial dari perusahaan. Hal ini dapat mempengaruhi profit yang di dapat oleh perusahaan. Hal ini karena perusahaan yang tidak memperhatikan kondisi sosial masyarakat dan lingkunganya cenderung tidak akan mendapatkan dukungan dari masyarakat. Begitu juga sebaliknya, perusahaan yang peduli terhadap masyarakat akan mendapatkan perhatian dari masyarakat dan akan cenderung untuk memilih produk yang mereka tawarkan.Dengan demikian,baik atau tidaknya pelaksanaan CSR yang dilakukan perusahaan dapat diukur melalui profit yang diperoleh oleh perusahaan.

Berdasarkan latar belakang yang telah diuraikan diatas, penulis tertarik untuk melakukan penelitian dengan judul "PENGARUH PENGUNGKAPAN CORPORATE SOCIAL RESPONSIBILITY TERHADAP PROFITABILITAS PERUSAHAAN" (Studi Empiris pada Perusahaan Sektor Industri Rokok yang Terdaftar di Bursa Efek Indonesia Tahun 2016-2019).

\section{REVIU LITERATUR}

Corporate Social Responsibility (CSR) pertama kali diungkapkan oleh Howard R. Bowen (1953) sebagai kewajiban pengusaha (perusahaan) untuk mengejar kebijakan, membuat keputusan, atau mengikuti garis tindakan yang diinginkan dalam hal tujuan dan nilai masyarakat. Dalam hal ini, perusahaan sebagai pelayan masyarakat sehingga perlu memperhatikan nilai-nilai yang secara social telah tumbuh di masyarakat dan tidak dianjurkan untuk menempatkan nilai perusahaan sendiri di atas nilai masyarakat. Carrol (1991) memperkenalkan penekanan pentingnya tanggung jawab perusahaan dalam merespon tanggung jawab social masyarakat dalam 4 aspek, yaitu ekonomi, hukum, etika, dan filantropi. Keempat aspek tersebut digambarkan sebagai piramida berjenjang.

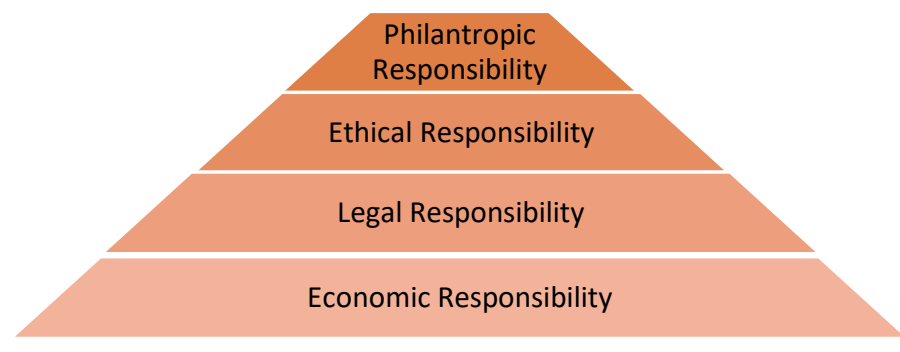

Gambar 1. Piramida CSR

Bentuk piramida tersebut mengindikasikan bahwa perusahaan harus memenuhi aspek tanggung jawab dari lapisan paling dasar terlebih dahulu sebelum melaksanakan tanggung jawab di

DOI: $10.52362 /$ jisamar.v5i2.379

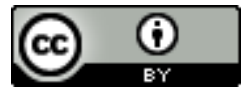

Ciptaan disebarluaskan di bawah Lisensi Creative Commons Atribusi 4.0 Internasional 
Journal of Information System, Applied, Management, Accounting and Research.

http://journal.stmikjayakarta.ac.id/index.php/jisamar,

jisamar@stmikjayakarta.ac.id , jisamar2017@gmail.com

e-ISSN: 2598-8719 (Online), p-ISSN: 2598-8700 ( Printed), Vol. 5 No.2 Mei 2021

atasnya. Lapisan paling bawah, yaitu aspek ekonomi, merupakan pondasi dari aspek tanggung jawab di atasnya. Tanggung jawab ekonomi mensyaratkan perusahaan untuk mencapai keuntungan yang diharapkan. Dengan ini, perusahaan akan lebih mudah untuk mewujudkan tanggung jawab lain di atasnya. Lapisan kedua adalah tanggung jawab hukum di mana perusahaan harus mematuhi hukum dan regulasi yang berlaku untuk memastikan praktik bisnis dilakukan secara bertanggung jawab. Lapisan ketiga adalah tanggung jawab dari sisi etika yang membuat perusahaan di mana pun berada untuk tetap melakukan kegiatan yang benar dan adil untuk semua elemen pemangku kepentingan. Tingkat teratas adalah tanggung jawab filantropis yang memastikan perusahaan sebagai warga negara yang baik bagi masyarakat dan menyumbangkan sumber daya jika diperlukan.

Dua lapisan teratas piramida, filantropis dan etika, ditekankan dalam teori kontrak social dari CSR di mana perusahaan dipadang sebagai bagian dari komunitas masyarakat yang untuk itu perlu berkontribusi pada masyarakat seperti layaknya individu (Dahl 1972).

Industry rokok merupakan salah satu "sinful industry" seperti industry alcohol dan judi (Ye Cai, Hoje Jo, dan Carrie Pan, 2011). Perusahaan di industry kontroversial tersebut, khususnya rokok, juga melakukan kegiatan CSR dengan berkontribusi dalam komunitas masyarakat sebagai usaha untuk mengembangkan tata kelola perusahaan yang efektif, memastikan keberlangsungan perusahaan (sustainability) melalui praktik bisnis yang sehat yang mengutamakan akuntabilitas, transparansi informasi, dan filantropi perusahaan. Pertanyaan yang selalu muncul: bagaimana bisa perusahaan melakukan kegiatan berorientasi social sementara ia memproduksi barang yang membahayakan masyarakat?

Terdapat beberapa pandangan mengenai CSR pada perusahaan kontroversial. Salah satu pendapat menyatakan bahwa CEO dari perusahaan di sektor industri yang kontroversial merupakan manajer yang tidak bermoral dan mereka menggunakan CSR sebagai sarana untuk meningkatkan keuntungan pribadi mereka sendiri dari membangun reputasi sebagai warga sosial dengan mengorbankan kekayaan pemegang saham (barnea dan Rubin, 2010). Ye Cai, Hoje Jo, dan Carrie Pan (2011) menyebut penjelasan tersebut sebagai window-dressing hypothesis.

Di sisi lain, Porter dan Kramer (2011) menyatakan bahwa masalah sosial yang bersinggungan dengan bisnis inti perusahaan bisa menjadi tempat di mana perusahaan menciptakan nilai bagi masyarakat (creating shared value). Penjelasan ini menguatkan keterkaitan positif antara kegiatan CSR dengan nilai perusahaan bagi perusahaan di industry kontroversial. Ye Cai, Hoje Jo, dan Carrie Pan (2011) menyebut penjelasan tersebut sebagai value-enhancement hypothesis. Pernyataan tersebut akan digali penulis dalam penelitian ini, terutama dalam hal pengungkapan CSR.

Di Indonesia, pengaturan mengenai CSR disebutkan sebagai Tanggung Jawab Social dan Lingkungan. Pasal 74 Undang-Undang Nomor 40 Tahun 2007 tentang Perseroan Terbatas

DOI: $10.52362 /$ jisamar.v5i2.379

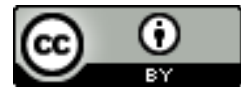

Ciptaan disebarluaskan di bawah Lisensi Creative Commons Atribusi 4.0 Internasional 
Journal of Information System, Applied, Management, Accounting and Research. http://journal.stmikjayakarta.ac.id/index.php/jisamar, jisamar@stmikjayakarta.ac.id , jisamar2017@gmail.com

e-ISSN: 2598-8719 (Online), p-ISSN: 2598-8700 ( Printed), Vol. 5 No.2 Mei 2021

menyatakan bahwa perseroan yang menjalankan kegiatan usahanya di bidang dan/atau berkaitan dengan sumber daya alam wajib melaksanakan Tanggung Jawab Sosial dan Lingkungan. Tanggung Jawab Sosial dan Lingkungan tersebut merupakan kewajiban perseroan yang dianggarkan dan diperhitungkan sebagai biaya perseroan yang pelaksanaannya dilakukan dengan memperhatikan kepatutan dan kewajaran. Apabila perseroan tidak melaksanakan kewajiban Tanggung Jawab Sosial dan Lingkungan tersebut, terdapat sanksi sesuai dengan ketentuan peraturan perundang-undangan.

Dalam undang-undang tersebut juga disebutkan mengenai pengungkapan tanggung jawab social dan lingkungan / CSR perusahaan. Pasal 66 ayat (2) poin c Undang-Undang Nomor 40 Tahun 2007 tentang Perseroan Terbatas menyebutkan bahwa laporan pelaksanaan tanggung jawab social dan lingkungan menjadi salah satu item yang harus dimuat dalam laporan tahunan perusahaan.

\section{Kerangka Pemikiran dan Pengembangan Hipotesis}

\section{Corporate Social Responsibility (CSR)}

CSR dikenal pertama kali pada tahun 1953 melalui tulisan Social Responsibility of the Businessman. Tanggung jawab sosial merujuk pada tindakan yang diambil sebuah organisasi yang secara hukum diperlukan untuk menjaga atau meningkatkan kesejahteraan makhluk hidup (Fred dan Forest, 2017). CSR kian menjadi topik yang banyak didiskusikan oleh dunia bisnis. Bahkan surat kabar terkemuka di AS, Financial Times, memilih perusahaan terkemuka salah satu kriterianya ialah kontribusi perusahaan tersebut terhadap perekonomian serta masyarakat.

Berikut definisi CSR yang disampaikan oleh Pemerintah Inggris:

"The voluntary actions that business can take, over and above compliance with minimum requirements, to address both its own competitive interest and interests of wider society" (www.CSR.gov.uk UK Government)

\section{Profitabilitas}

Secara sederhana, profitabilitas merupakan tingkat kemampuan suatu perusahaan dalam memperoleh laba atau keuntungan. Profitabilitas menggambarkan kemampuan perusahaan mendapatkan laba melalui semua kemampuan sumber daya yang ada seperti kegiatan penjualan, kas, modal, jumlah karyawan, jumlah cabang, dan sebagainya (Sofyan Syafri Harahap, 2008).

Wahlen et al. (2015) menyatakan bahwa rasio keuangan bermanfaat untuk menilai profitabilitas dan risiko yang ada pada suatu perusahaan. Rasio berguna dalam menunjukkan hubungan yang ada di antara data laporan keuangan, serta dapat digunakan untuk membandingkan satu

DOI: $10.52362 /$ jisamar.v5i2.379

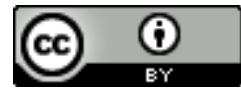

Ciptaan disebarluaskan di bawah Lisensi Creative Commons Atribusi 4.0 Internasional 
Journal of Information System, Applied, Management, Accounting and Research. http://journal.stmikjayakarta.ac.id/index.php/jisamar, jisamar@stmikjayakarta.ac.id , jisamar2017@gmail.com

e-ISSN: 2598-8719 (Online), p-ISSN: 2598-8700 ( Printed), Vol. 5 No.2 Mei 2021

perusahaan dengan perusahaan yang lain, atau bisa juga digunakan untuk menganalisis satu perusahaan dalam jangka waktu tertentu (Kramer dan Johnson, 2009).

Multafia Almar, Rima Rachmawati, dan Asri Murni tahun 2012 lalu melakukan riset terhadap perusahaan industri semen yang menguasai pangsa pasar domestik, diantaranya ada PT Semen Gresik Tbk, PT Indocement Tunggal Prakarsa Tbk, dan PT Holcim Indonesia Tbk. Riset tersebut menyimpulkan bahwa terdapat pengaruh positif dan signifikan antara pengungkapan CSR dengan profitabilitas perusahaan yang diukur dengan ROA dan NPM. Sehingga dapat dikatakan bahwa semakin tinggi pengungkapan CSR perusahaan akan meningkatkan profitabilitas perusahaan.

Penelitian yang akan penulis lakukan saat ini adalah penelitian yang mirip dengan penelitian Almar et al, yang membedakan adalah lingkup periode dan jenis perusahaan. Dalam penelitian ini, penulis akan melakukan riset terhadap perusahaan rokok di Indonesia yang terdaftar dalam BEI untuk periode tahun 2016 sampai dengan 2019. Sedangkan penelitian yang dilakukan Almar et al adalah terhadap perusahaan industri semen di Indonesia yang menguasai pangsa pasar dan juga terdaftar di BEI dengan periode tahun 2008 sampai dengan 2010. Dengan hasil penelitian tersebut, penulis juga mengembangkan hipotesis atas riset ini yaitu pengungkapan CSR berpengaruh positif dan signifikan terhadap profitabilitas perusahaan. Profitabilitas perusahaan dicerminkan melalui ROA dan NPM.

H1 : Pengungkapan Corporate Social Responsibility (CSR) berpengaruh positif signifikan terhadap Net Profit Margin (NPM)

H2 : Pengungkapan Corporate Social Responsibility (CSR) berpengaruh positif signifikan terhadap Return On Asset (ROA)

\section{Metode Penelitian 4.1 Jenis Data}

Data yang digunakan dalam penelitian ini adalah data sekunder yang diambil dari Bursa Efek Indonesia (BEI). Data penelitian ini merupakan data panel yang merupakan perpaduan data time series dan juga data cross sectional yang diambil dari Laporan Tahunan perusahaan di website Bursa Efek Indonesia.Jumlah data yang digunakan dalam penelitian ini adalah data sampling dari 4 Perusahaan dengan jangka waktu 4 tahun dari tahun 2016 sampai dengan tahun 2019.Sehingga total data sebanyak 16 data.Sampel diperoleh secara purposive sampling dengan mengutamakan kelengkapan data yang disediakan pada Bursa Efek Indonesia.Adapun perusahaan yang menjadi sampel dalam penelitian ini dapat dilihat pada Tabel 4.1 berikut.

Tabel 4.1 Perusahaan yang terdaftar di BEI sebagai sampel penelitian

DOI: $10.52362 /$ jisamar.v5i2.379

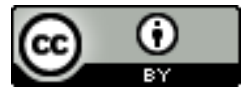

Ciptaan disebarluaskan di bawah Lisensi Creative Commons Atribusi 4.0 Internasional 
Journal of Information System, Applied, Management, Accounting and Research. http://journal.stmikjayakarta.ac.id/index.php/jisamar, jisamar@stmikjayakarta.ac.id , jisamar2017@gmail.com

e-ISSN: 2598-8719 (Online), p-ISSN: 2598-8700 ( Printed), Vol. 5 No.2 Mei 2021

\begin{tabular}{|c|l|}
\hline No & \multicolumn{1}{|c|}{ Perusahaan Rokok } \\
\hline 1 & Handjaya Mandala Sampoerna Tbk (HMSP) \\
\hline 2 & Gudang Garam Tbk (GGRM) \\
\hline 3 & Bantoel International Investama Tbk (RMBA) \\
\hline 4 & Wismilak Inti Makmur Tbk (WIIM) \\
\hline
\end{tabular}

Sumber: data diolah sendiri

\subsection{Defenisi Operasional Variabel}

Varabel dalam penelitian ini didefenisikan sebagai berikut:

a. Tingkat pengungkapan CSR / CSR Disclosure Index (Y)

Pengungkapan CSR dalam penelitian ini merujuk pada pengungkapan kegiatan CSR di 4 perusahaan rokok dalam laporan tahunan dari tahun 2016 hingga 2019, seperti yang disyaratkan dalam Undang-Undang Nomor 40 Tahun 2007 tentang Perseroan Terbatas. Indicator yang digunakan dalam mengukur tingkat pengungkapan CSR adalah komponen CSR menurut Edy Rismanda Sembiring (2005). Sembiring (2005) mengelompokkan indikator pengungkapan CSR menjadi 7 bagian, yaitu lingkungan, energi, kesehatan dan keselamatan kerja, lain-lain tentang tenaga kerja, produk, keterlibatan masyarakat, dan umum. Proses pengukuran CSR Disclosure Index (CSRDI) adalah dengan metode content analysis, yang menggunakan teknik indexing dengan pendekatan yes/no. Aplikasi pengkuantifikasian dalam teknik ini adalah memberikan nilai "1" pada pernyataan indicator yang bahwa pengungkapan CSR telah dilakukan atau yes. Nilai "0" akan diberikan apabila pernyataan indicator tidak diungkapkan dalam laporan tahunan perusahaan. Dengan jumlah 79 pernyataan indicator, CSRDI dapat diperoleh dari rumus berikut.

Keterangan:

$$
C S R D I=\frac{\sum X i}{n}
$$

CSRDI = CSR Disclosure Index atau tingkat pengungkapan CSR suatu perusahaan

$\mathrm{Xi}=$ nilai " 1 " (ketika pernyataan indicator pengungkapan terpenuhi)

$\mathrm{N}=$ = jumlah indikator pengungkapan menurut Sembiring (2005), yaitu 79.

b. Net Profit Margin (X1)

Net Profit Margin (NPM) merupakan rasio profitabilitas yang menggambarkan kemampuan perusahaan dalam menghasilkan laba yang berasal dari hasil kegiatan operasionalnya (Almar, Rachmawati, Murni, 2012). Terkait dengan pengungkapan CSR, NPM berarti pengaruh pengungkapan CSR yang dilakukan perusahaan terhadap profit atau keuntungan yang didapat perusahaan. Rasio ini merupakan perbandingan antara laba bersih setelah pajak dengan penjualan seperti rumus berikut.

$$
N P M=\frac{\text { laba bersih }}{\text { penjualan }}
$$

DOI: $10.52362 /$ jisamar.v5i2.379

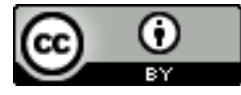

Ciptaan disebarluaskan di bawah Lisensi Creative Commons Atribusi 4.0 Internasional 
Journal of Information System, Applied, Management, Accounting and Research.

http://journal.stmikjayakarta.ac.id/index.php/jisamar, jisamar@stmikjayakarta.ac.id , jisamar2017@gmail.com

e-ISSN: 2598-8719 (Online), p-ISSN: 2598-8700 ( Printed), Vol. 5 No.2 Mei 2021

Keterangan:

NPM = Net Profit Margin atau tingkat laba yang dihasilkan per RP1 penjualan oleh perusahaan

Laba bersih = keuntungan bersih perusahaan dalam satu periode buku

Penjualan = jumlah total penjualan perusahaan dalam satu tahun buku

c. Return on Asset (X2)

Return on Asset (ROA) merupakan rasio profitabilitas yang menunjukkan efisiensi penggunaan asset oleh manajemen dalam rangka menghasilkan laba (Lubica Lesakova, 2007). Rasio ini diapatkan dengan membagi laba bersih dengan total asset perusahaan seperti dalam rumus berikut.

Keterangan:

$$
R O A=\frac{\text { laba bersih }}{\text { total aset }}
$$

ROA = Return on Asset atau tingkat efisiensi penggunaan asset perusahaan dalam menghasilkan laba dalam satu periode buku

Laba bersih = keuntungan bersih perusahaan dalam satu periode buku

Total asset $=$ jumlah total asset perusahaan

\subsection{Teknik Analisis Data}

Teknik analisis data yang digunakan dalam penelitian ini adalah regresi linear berganda dengan menggunakan program STATA versi 16. Untuk mengetahui pengaruh Corporate Social Responsibility terhadap Return on Asset (ROA) dan Net Profit Margin (NPM), dilakukan uji baik secara simultan (Uji F) maupun secara parsial (Uji t) dengan tingkat kepercayaan 95\% ( $\alpha=5 \%$ ).

\section{HASIL DAN PEMBAHASAN}

\subsection{Statistik Deskriptif}

Hasil uji statistik deskriptif menggunakan aplikasi STATA menghasilkan output yang menggambarkan rata-rata, standar deviasi, maksimum dan minimum dari variabel dependen dan independent sehingga dapat dilihat secara statistik bagaimana deskripsi dari variabel tersebut. Hasil dari uji statistic deskriptif tersebut dapat dilihat pada gambar dibawah ini.

DOI: $10.52362 /$ jisamar.v5i2.379

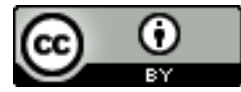

Ciptaan disebarluaskan di bawah Lisensi Creative Commons Atribusi 4.0 Internasional 
Journal of Information System, Applied, Management, Accounting and Research. http://journal.stmikjayakarta.ac.id/index.php/jisamar, jisamar@stmikjayakarta.ac.id , jisamar2017@gmail.com

e-ISSN: 2598-8719 (Online), p-ISSN: 2598-8700 ( Printed), Vol. 5 No.2 Mei 2021

\begin{tabular}{|r|rrrrr|}
\hline Variable & Obs & Mean & Std. Dev. & Min & Max \\
\hline ROA & 16 & .0983661 & .1345152 & -.1548378 & .3002293 \\
NPM & 16 & .0542039 & .0693896 & -.1084723 & .1336826 \\
CSR & 16 & .4493671 & .1054008 & .2658228 & .5949367 \\
\hline
\end{tabular}

Sumber: data diolah sendiri

Semua variabel memiliki jumlah data yang sama, yaitu masing-masing 16 data terobservasi. Ratarata nilai variabel dependen ROA adalah 0,098. Untuk variabel dependen selanjutnya, yaitu NPM memiliki rata-rata nilai yang lebih rendah sebesar 0,054. Sementara itu, rata-rata nilai variabel independent, yaitu CSR atau menunjukkan CSRDI adalah 0,449.

Rentang nilai minimal dan maksimal dari variabel dependen ROA adalah -0,155 dan 0,300. Rentang ini cukup lebar dengan didukung oleh data standar deviasi yang besar di antara seluruh variabel yaitu sebesar 0,135 . Data tersebut mengindikasikan bahwa variabel ROA lebih mudah terpengaruh oleh variabel independent. Sementara itu, untuk rentang variabel NPM dari $-0,108$ hingga 0,134 menghasilkan standar deviasi sebesar 0,069. Terakhir, variabel independent CSR memiliki rentang 0.266 hingga 0,595 dengan standar deviasi 0,105 .

\subsection{Uji Model}

\subsubsection{Uji Chow}

Uji Chow adalah uji yang dilakukan untuk memilih model regresi mana yang terbaik antara Pooled Least Square (PLS) dan Fixed Effect (FE),dengan hipotesis sebagai berikut :

H0 : Model Pooled Least Square

H1 : Model Fixed Effect

Hasil dari pengujian ini dapat dilihat pada probabilitas $\mathrm{F}$ test pada regresi model fixed effect,dimana tingkat signifikansi sebesar 0.05 .Hasil pengujian tersebut dapat dilihat pada gambar 5.2.1 sebagai berikut:

DOI: $10.52362 /$ jisamar.v5i2.379

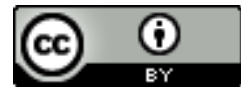

Ciptaan disebarluaskan di bawah Lisensi Creative Commons Atribusi 4.0 Internasional 


\section{Journal of Information System, Applied, Management, Accounting and Research.}

http://journal.stmikjayakarta.ac.id/index.php/jisamar, jisamar@stmikjayakarta.ac.id , jisamar2017@gmail.com

e-ISSN: 2598-8719 (Online), p-ISSN: 2598-8700 ( Printed), Vol. 5 No.2 Mei 2021

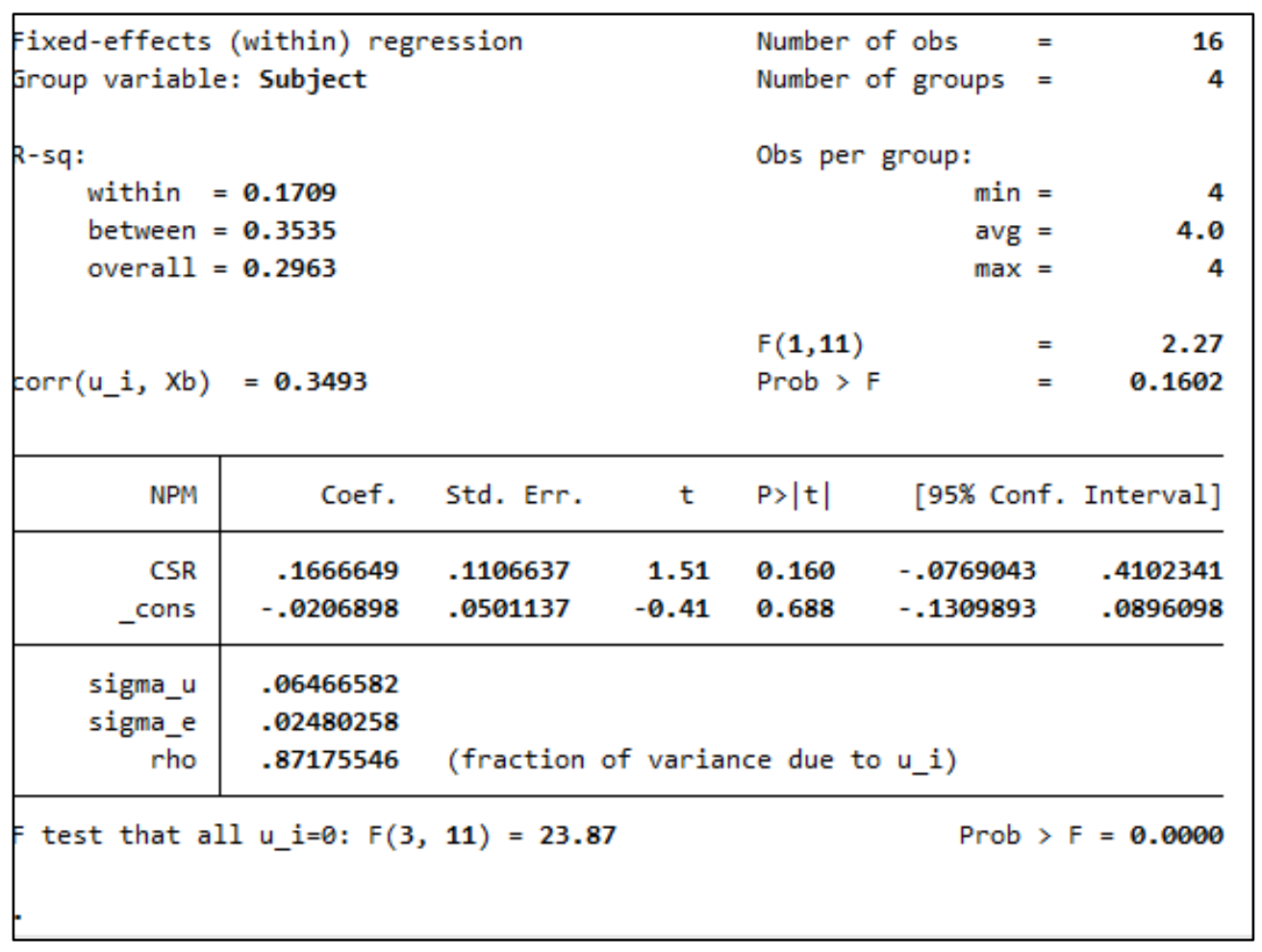

Sumber: data diolah sendiri

Berdasarkan hasil dari uji diatas,menunjukkan bahwa P Value (Prob>F) lebih kecil dari tingkat signifikansi sebesar 5\%. Dengan demikian menolak H0 sehingga data lebih mendekati model fixed effect daripada model pooled least square.

\subsubsection{Uji LM}

Uji LM adalah uji yang dilakukan untuk memilih model regresi yang terbaik antara pooled least square dan random effect,dengan hipotesis sebagai berikut:

H0 : Model Pooled Least Square

H1 : Model Random Effect

Hasil dari pengujian ini dapat dilihat pada gambar 5.2.2 sebagai berikut:

DOI: 10.52362/jisamar.v5i2.379

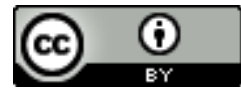

Ciptaan disebarluaskan di bawah Lisensi Creative Commons Atribusi 4.0 Internasional 


\section{Journal of Information System, Applied, Management, Accounting and Research. http://journal.stmikjayakarta.ac.id/index.php/jisamar, jisamar@stmikjayakarta.ac.id, jisamar2017@gmail.com \\ e-ISSN: 2598-8719 (Online), p-ISSN: 2598-8700 ( Printed), Vol. 5 No.2 Mei 2021}

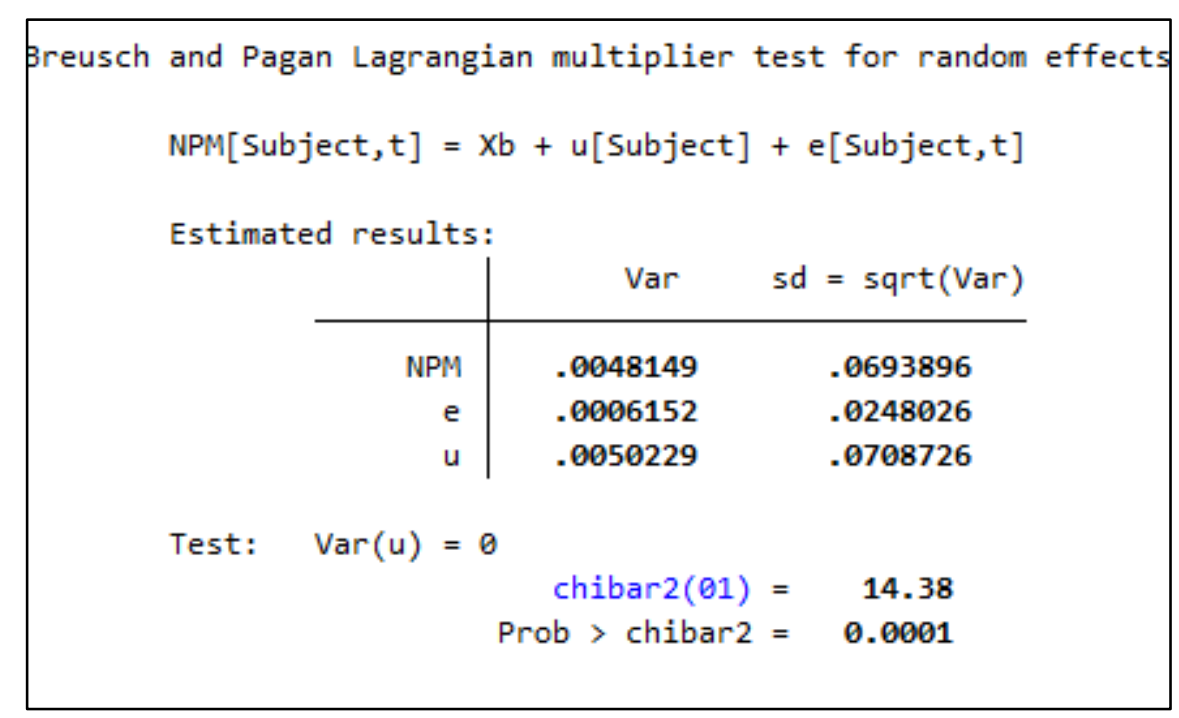

Sumber: data diolah sendiri

Probabilitas pada uji diatas lebih kecil dari tingkat signifikansi sebesar 5\%. Dengan demikian reject $\mathrm{H} 0$ sehingga data lebih mendekati model random effect daripada pooled least square. Dengan demikian,untuk menentukan model terbaik maka harus melaukan uji terakhir yaitu uji Hausman.

\subsubsection{Uji Hausman}

Uji Hausman merupakan uji yang dilakukan untuk memilih model terbaik antara random effect dan fixed effect,dengan hipotesis sebagai berikut:

H0 : Model Random Effect

H1 : Model Fixed Effect

Hasil pengujian dapat dilihat pada gambar 5.2.3 sebagai berikut:

DOI: $10.52362 /$ jisamar.v5i2.379

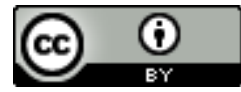

Ciptaan disebarluaskan di bawah Lisensi Creative Commons Atribusi 4.0 Internasional 


\section{Journal of Information System, Applied, Management, Accounting and Research. http://journal.stmikjayakarta.ac.id/index.php/jisamar, jisamar@stmikjayakarta.ac.id , jisamar2017@gmail.com \\ e-ISSN: 2598-8719 (Online), p-ISSN: 2598-8700 ( Printed), Vol. 5 No.2 Mei 2021}

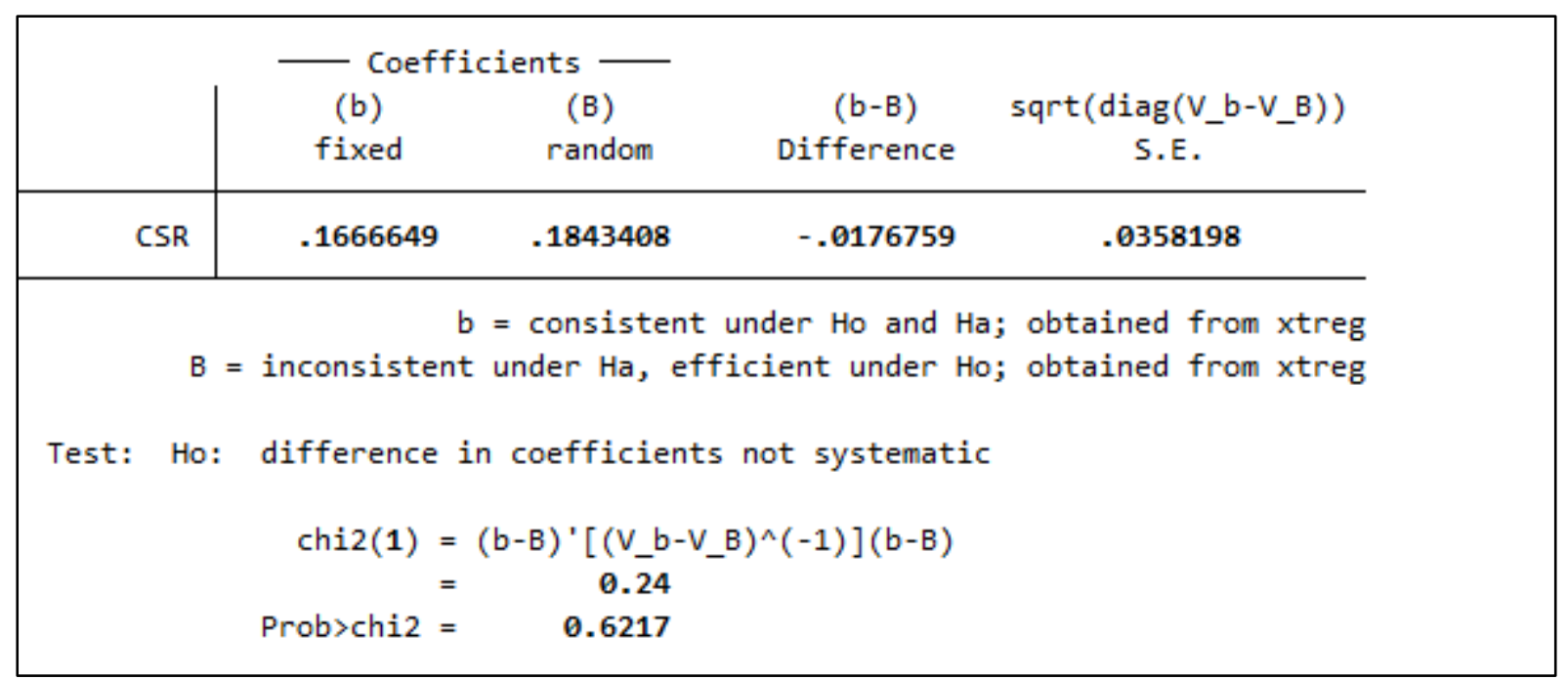

Sumber: data diolah sendiri

Hasil uji Hausman diatas menunjukkan probabilitas yang tidak signifikan.Itu artinya model random effect lebih baik daripada model fixed effect.Dengan demikian,model terbaik dalam penelitian ini adalah model random effect.

\subsection{Pengujian Hipotesis}

\subsubsection{Analisis Regresi Berganda}

Berdasarkan pengujian STATA 16 untuk menentukan model regresi yang tepat menggunakan uji Chow,uji LM dan uji Hausman,model regresi yang baik digunakan pada semua hipotesis dalam penelitian ini adalah model Random Effect(RE).Setelah dilakukan uji asumsi klasik dan memenuhi persyaratan pengujian,maka dilakukan regresi panel data.Hasil regresi model random effect untuk pengaruh Pengungkapan CSR terhadap ROA adalah sebagai berikut.

DOI: $10.52362 /$ jisamar.v5i2.379

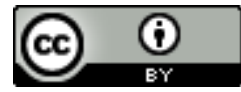

Ciptaan disebarluaskan di bawah Lisensi Creative Commons Atribusi 4.0 Internasional 
Journal of Information System, Applied, Management, Accounting and Research.

http://journal.stmikjayakarta.ac.id/index.php/jisamar , jisamar@stmikjayakarta.ac.id , jisamar2017@gmail.com

e-ISSN: 2598-8719 (Online), p-ISSN: 2598-8700 ( Printed), Vol. 5 No.2 Mei 2021

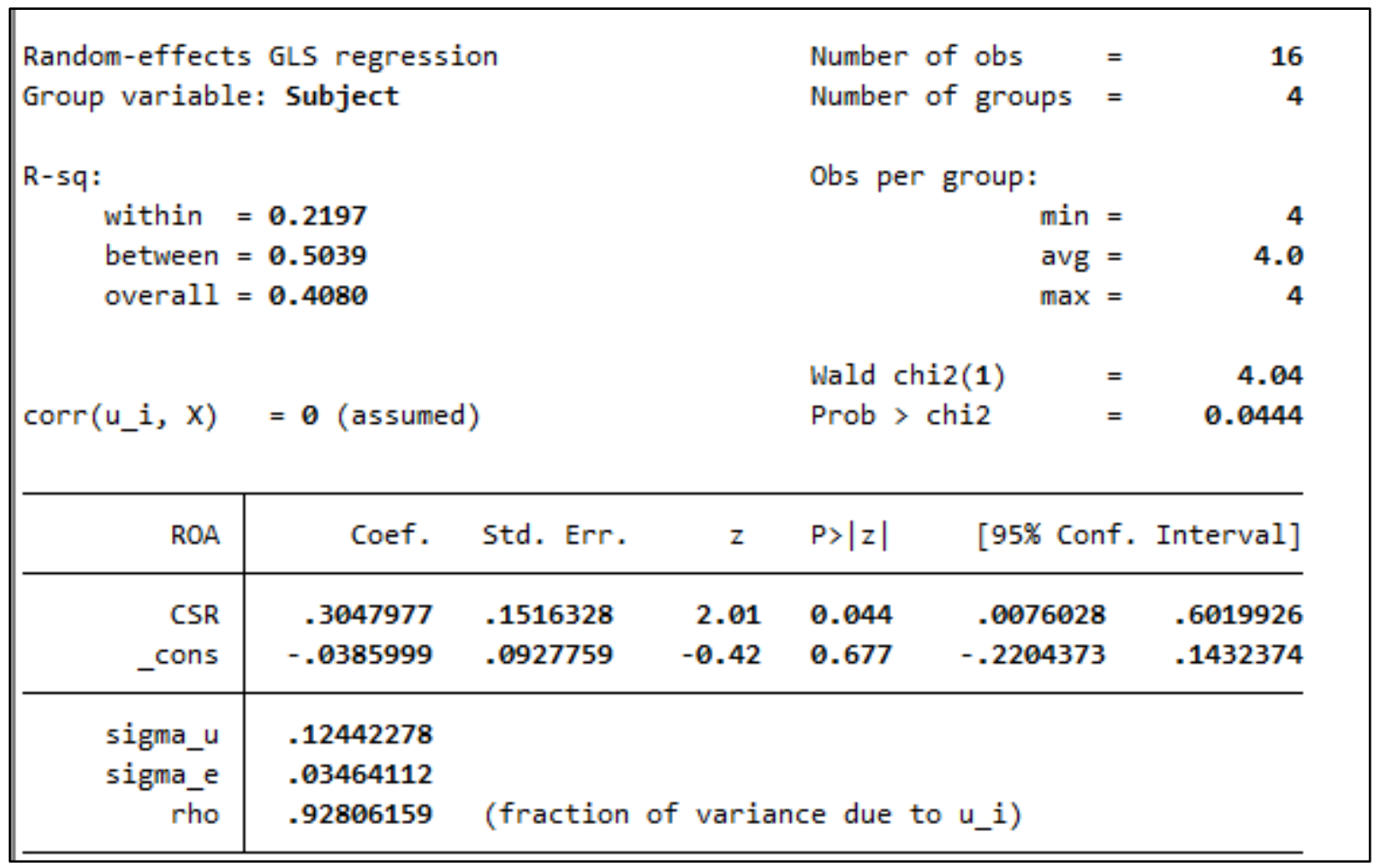

Sumber: data diolah sendiri

Sedangkan untuk pengaruh pengungkapan CSR terhadap NPM adalah sebagai berikut.

DOI: $10.52362 /$ jisamar.v5i2.379

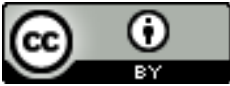

Ciptaan disebarluaskan di bawah Lisensi Creative Commons Atribusi 4.0 Internasional 
Journal of Information System, Applied, Management, Accounting and Research.

http://journal.stmikjayakarta.ac.id/index.php/jisamar, jisamar@stmikjayakarta.ac.id , jisamar2017@gmail.com

e-ISSN: 2598-8719 (Online), p-ISSN: 2598-8700 ( Printed), Vol. 5 No.2 Mei 2021

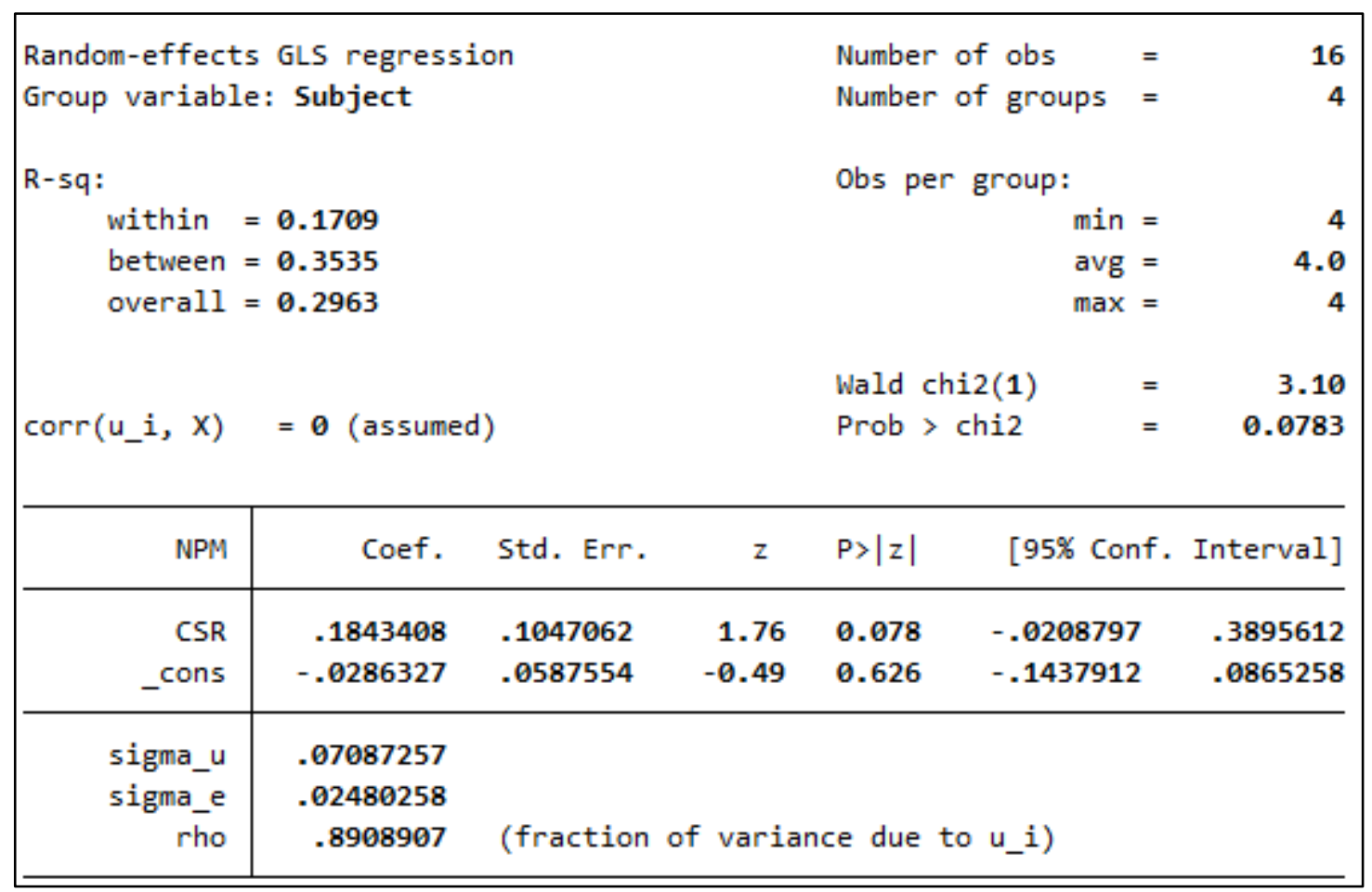

Sumber: data diolah sendiri

\subsubsection{Uji Hipotesis (Uji t)}

Uji t dilakukan untuk menguji hipotesis apakah variabel independen yaitu NPM dan ROA memiliki pengaruh positif signifikan terhadap variabel dependen, yaitu Pengungkapan Corporate Social Responsibility (CSR). Berikut hasil uji statistik t dalam penelitian ini:

Pengaruh CSR terhadap Net Profit Margin (H1)

H1 : Pengungkapan Corporate Social Responsibility (CSR) berpengaruh positif signifikan terhadap Net Profit Margin (NPM)

\begin{tabular}{r|rrrrrr}
\hline NPM & Coef. & Std. Err. & $t$ & P > t I & [95\% Conf. Interval] \\
\hline CSR & .358364 & .1475968 & 2.43 & 0.029 & .0418003 & .6749276 \\
- cons & -.106833 & .0680141 & -1.57 & 0.139 & -.2527087 & .0390427
\end{tabular}

Sumber: data diolah sendiri

DOI: 10.52362/jisamar.v5i2.379

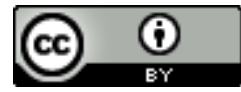

Ciptaan disebarluaskan di bawah Lisensi Creative Commons Atribusi 4.0 Internasional 
Berdasarkan hasil uji statistik-t di atas, diperoleh nilai t-hitung sebesar 2,43. Selanjutnya nilai thitung tersebut akan dibandingkan dengan nilai t-tabel yang nilainya adalah 0,029. Dengan demikian karena 0,029 kurang dari batas signifikansi 0,05 hipotesis $\mathrm{H} 1$ gagal ditolak.

\section{Pengaruh CSR terhadap Return On Asset (H2)}

H2 : Pengungkapan Corporate Social Responsibility (CSR) berpengaruh positif signifikan terhadap Return On Asset (ROA)

\begin{tabular}{r|rrrrrr}
\hline ROA & Coef. & Std. Err. & $t$ & P $>$ |t| & [95\% Conf. Interval] \\
\hline CSR & .8152195 & .2624293 & 3.11 & 0.008 & .2523647 & 1.378074 \\
- cons & -.2679667 & .12093 & -2.22 & 0.044 & -.5273357 & -.0085976 \\
\hline
\end{tabular}

Sumber: data diolah sendiri

Berdasarkan hasil uji statistik-t di atas, diperoleh nilai t-hitung sebesar 3,11. Selanjutnya nilai thitung tersebut akan dibandingkan dengan nilai t-tabel yang nilainya adalah 0,008 . Dengan demikian karena nilai 0,008 kurang dari batas signifikansi 0,05 hipotesis $\mathrm{H} 2$ gagal ditolak.

\section{SIMPULAN, SARAN, DAN KETERBATASAN PENELITIAN}

\subsection{Simpulan}

Berdasarkan hasil dan pembahasan,maka dapat diambil simpulan sebagai berikut:

a) Pengungkapan CSR berpengaruh signifikan terhadap Return on Asset (ROA). Hal ini dikarenakan nilai $p$-value lebih kecil dari kriteria signifikansi sebesar 5\%, yaitu bernilai 0,04 atau $4 \%$. Variabel CSR memiliki pengaruh positif terhadap variabel profitabilitas yang diukur menggunakan ROA yang dapat dilihat dari nilai koefisien regresi yang bernilai positif sebesar 0,304. Ini berarti semakin banyak indicator CSR yang diungkapkan oleh perusahaan maka ROA perusahaan akan semakin meningkat. Berdasarkan hasil $\mathrm{R}^{2}$ dapat diketahui sebesar $40 \%$. Ini berarti pengungkapan CSR hanya mempengaruhi profitabilitas perusahaan yang diukur menggunakan ROA sebesar $40 \%$ sedangkan sisanya yaitu sebesar $60 \%$ dipengaruhi oleh variabel lainnya diluar penelitian ini.

b) Pengungkapan CSR tidak memiliki pengaruh yang signifikan terhadap Net Profit Margin (NPM). Hal ini ditunjukkan oleh nilai p-value yang melebihi batas kriteria signifikansi sebesar $<5 \%$ yaitu bernilai 0,078 atau 7,8\%. Namun,variabel CSR memiliki pengaruh positif terhadap variabel Profitabilitas yang diukur menggunakan NPM yang dapat dilihat

DOI: $10.52362 /$ jisamar.v5i2.379

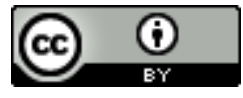

Ciptaan disebarluaskan di bawah Lisensi Creative Commons Atribusi 4.0 Internasional 
melalui nilai koefisien yang bernilai positif yaitu 0,18.Berdasarkan hasil $\mathrm{R}^{2}$ dapat diketahui sebesar 29\%. Ini berarti CSR mempengaruhi NPM sebesar 29\%, sisanya dijelaskan oleh variabel lain diluar penelitian ini

\subsection{Saran}

Saran untuk penelitian berikutnya, antara lain:

a) Menambah dan menggunakan sampel penelitian di sektor lainnya sehingga hasil penelitian tersebut dapat menggambarkan kondisi perusahaan secara keseluruhan yang terdaftar di Bursa Efek Indonesia.

b) Menggunakan periode penelitian yang lebih lama sehingga dapat diketahui dampak jangka panjang dari pengungkapan CSR terhadap ROA dan NPM pada perusahaan terbuka di Indonesia.

c) Penelitian selanjutnya juga dapat menggunakan variabel dependen yang lain diluar dari profitabilitas perusahaan.Peneliti selanjutnya dapat menggunakan proksi kinerja keuangan yang lainnya.

\subsection{Keterbatasan Penelitian}

Penelitian ini menggunakan sampel perusahaan yang berada pada subsektor rokok, sehingga tidak dapat mencerminkan kondisi keseluruhan pada perusahaan manufaktur dan keseluruhan perusahaan yang terdaftar di Bursa Efek Indonesia. Perusahaan yang terdaftar di BEI yang merupakan bagian dari sektor manufaktur, subsektor rokok juga jumlahnya terbatas, hanya 5 perusahaan, di mana 1 perusahaan yaitu Indonesian Tobacco Tbk (ITIC) baru IPO tahun 2019 sehingga tidak dapat dijadikan sampel dalam penelitian ini. Selain itu,periode waktu yang kami jadikan sebagai sampel hanya 4 periode dari 2016-2020 sehingga belum bisa mencerminkan kondisi keseluruhan perusahaan khususnya perusahaan-perusahaan yang dalam kegiatan produksinya atau produknya menimbulkan kerugian bagi masyarakat.

\section{REFERENSI}

[1] Aida Yulia, A. (2014). Analisis Perbedaan Pengungkapan Corporate Social Responsibility Pada Perusahaan High Profile dan Low Profile (Studi Empiris Perusahaan Manufaktur yang Terdaftar di BEI). JURNAL DINAMIKA AKUNTANSI DAN BISNIS .

[2] Bowen, H. R. (1953). Social Responsibilities of The Businessman. Iowa City: University of Iowa Press.

[3] Claydon, J. (2009). Two Models of CSR and Sustainability. Issues in Social and Environmental Accounting .

DOI: $10.52362 /$ jisamar.v5i2.379

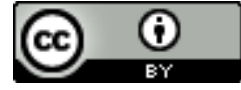

Ciptaan disebarluaskan di bawah Lisensi Creative Commons Atribusi 4.0 Internasional 


\section{Journal of Information System, Applied, Management, Accounting and Research. http://journal.stmikjayakarta.ac.id/index.php/jisamar, jisamar@stmikjayakarta.ac.id, jisamar2017@gmail.com \\ e-ISSN: 2598-8719 (Online), p-ISSN: 2598-8700 ( Printed), Vol. 5 No.2 Mei 2021}

[4] Hermuningsih, S. (2013). PROFITABILITY, GROWTH OPPORTUNITY, CAPITAL . Bulletin of Monetary, Economics and Banking.

[5] Indonesia, R. (2007). Undang-Undang Nomor 40 Tahun 2007 tentang Perseroan terbatas.

[6] Lesáková, L. (2007). Uses and Limitations of Profitability Ratio Analysis in Managerial Practice. 5th International Conference on Management, Enterprise and Benchmarking.

[7] Multafia Almar, R. R. (2012). PENGARUH PENGUNGKAPAN CORPORATE SOCIAL . Seminar Nasional Akuntansi \& Bisnis .

[8] Owens, C. R. (2016). The Importance of CSR in Business. Florida State University Libraries.

[9] Rehman, Q. S. (2011). Impacts of liquidity ratios on profitability (Case of oil and gas companies of Pakistan). Interdisciplinary Journal of Research in Business.

[10] T. Husain, S. N. (2020). Firm's Value Predicti on Based on Profitability . Finance \& Economics Review.

[11] Wilfred Boro Bahy, H. W. (n.d.). PENGARUH PENGUNGKAPAN CORPORATE SOCIAL RESPONSIBILITY TERHADAP KINERJA KEUANGAN PERUSAHAAN. Atmajaya.

[12] Ye Cai, H. J. (2011). Doing Well While Doing Bad? CSR in Controversial Industry. J Bus Ethics.

[13] Yulius Ardy Wiranata, Y. W. (2013). Pengaruh Struktur Kepemilikan Terhadap Profitabilitas Perusahaan Manufaktur di Indonesia . Jurnal Akuntansi dan Keuangan.

DOI: $10.52362 /$ jisamar.v5i2.379

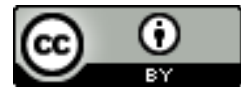

Ciptaan disebarluaskan di bawah Lisensi Creative Commons Atribusi 4.0 Internasional 


\section{Of Journal of Information System, Applied, JSA AMAR Management, Accounting and Research}

\section{SURAT PERNYATAAN KEASLIAN NASKAH (Statement of Authenticity of Status)}

Yang bertanda tangan di bawah ini menyatakan bahwa:

Judul naskah:

PENGARUH PENGUNGKAPAN CORPORATE SOCIAL, RESPONSIBILITY TERHADAP PROFITABILITAS PERUSAHAAN

Penulis:

1. Nama : Anikmah Musfirati e-mail : 1401170063 anikmah@pknstan.ac.id

2. Nama : Lorensius Ginting e-mail : 1401170043 lorensius@pknstan.ac.id

3. Nama : Muhammad Lukman Nur Hakim e-mail : 1401170026_lukman@pknstan.ac.id

Nama dan alamat penulis 1 (perwakilan) untuk korespondensi:

Nama : Anikmah Musfirati

Alamat: PKN STAN, Kalibondol RT 40 RW 20, Sentolo, Sentolo, Kulon Progo, DIY

Telp. : 085889407232

e-mail : 1401170063_anikmah@pknstan.ac.id

- Jurnal/Artikel tersebut di atas merupakan naskah asli, hasil karya penulis, dan bukan merupakanplagiat dari artikel atau karya ilmiah orang lain.

- Jurnal/Artikel tersebut di atas belum pernah dipublikasikan atau tidak sedang diajukan untukdimuat pada jurnal atau media lainnya.

- Apabila kemudian hari pernyataan ini tidak benar, maka penulis bersedia menerima sanksi dengan peraturan perundang-undangan yang berlaku.

Kulon Progo, 11 Mei 2021

Penulis 1,

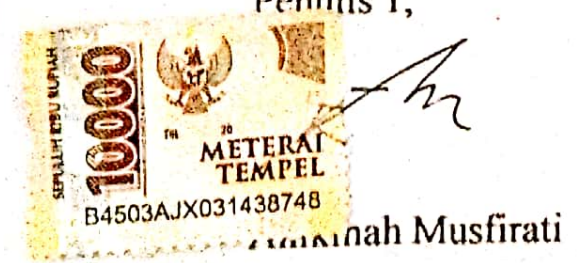

Penulis 2,

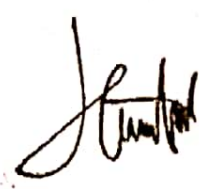

Lorensius Ginting
Penulis 3,

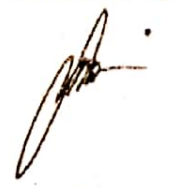

M. Lukman Nur Hakim 


\section{SIRA'T PERNYATAAN KESEDIAAN PUBLIKASI \\ (Statement of Publication Availability)}

Saya yang bertandatangan di bawnhini :

Nama

: Anikmah Musfirati

Asal lnstitusi

: PKN STAN

No.Telepon

: $0 \$ 5889407232$

Email

:1401170063_anikmah@pknstan.ac.id

Bersama ini saya menyatakan BERSEDIA/TWAAK-BERSE円ł*) untuk publikasi paper dengan judul :

\section{PENGARUH PENGUNGKAPAN CORPORATE SOCIAL RESPONSIBILITY TERHADAP PROFITABILITAS PERUSAHAAN}

Di JISAMAR (Journal of Information System, Applied, Management, Accounting and Research) : Vol 5 No 2 Tahun 2021

Saya menyatakan bahwa karya ilmiah tersebut di atas terbebas dari unsur plagiarism dan publikasi ganda (belum pernah dipublikasikan ke media manapun) serta tidak akan diterbitkan ulang pada Jumal/Buku dan atau majalah lainnya.

Saya juga bersedia membayar biaya publikasi pada JISAMAR (Journal of Information System, Applied. Management, Accounting and Research) sesuai ketentuan dan aturan yang berlaku**).

Demikian surat pernyataan ini dibuat dalam keadaan sehatwal'afiat tanpa paksaan dari pihak manapun dan agar dapat dipergunakan sebagaimana mestinya.

Kulon Progo, 11 Mei 2021

Yang Membuat Pernyataan

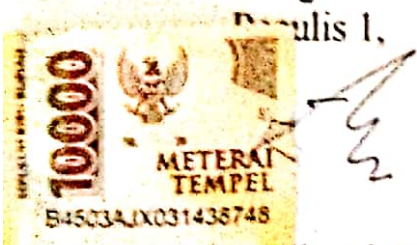

(Anikmah Musfirati)

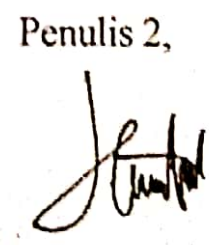

(Lorensius Ginting)

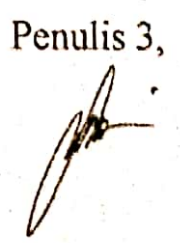

(M. Lukman Nur Hakim)

Nore:

- Coret yemg rickak sestrait(disestaikan)

* Dibạar sztetah artikel dimunatakan SIAP PUBLISH. 